\title{
Bicycling as a Response to La Violencia: The First Vuelta a Colombia, January 5-17, 1951
}

\author{
Jane M. Rausch/ University of Massachusetts Amherst
}

Sport historians have long recognized the relationship between sport and nationalism. As suggested by the editors of the recent anthology Sports and Nationalism in Latin/o America, more often than not, sports have been "a key arena for official forms of nationalism aimed at integrating a given society in the face of internal differences or for schemes aimed at taking advantage of sports' deep popularity to obtain political gains and legitimization" (Fernández L'Hoeste, McKee Irvin, Poblete, 2015,2). Even in Colombia, a country broken into disparate regions that geographically reinforce the emergence of distinctive cultures, sports at various times have surmounted this obstacle to play a crucial role in the establishment of a sense of national identity. ${ }^{1}$

One of these critical moments occurred in January 1951, when in the midst of a brutal civil war known as La Violencia, thirty-one cyclists embarked on the first Vuelta a Colombia, a bicycle race modeled after the Tour de France. For fifteen days accounts of their progress over 1,254 kilometers of roads - more often paths of sand, mud, and stone - through Cundinamarca, Tolima, Viejo Caldas and Valle del Cauca replaced daily reports of atrocities occurring throughout the country. Thanks to the development of radio (a medium that like sports became another method of binding Colombian regions together), commentator Carlos Arturo Rueda, aided by Julio César Cortés and Álvaro Muñoz, accompanied the cyclists in his own truck and broadcast details of the race using a transmitter and telephone lines. Rueda's minute-byminute account of the Vuelta's progress captivated national attention. As Patricia Londoño writes, "His ability to colorfully describe different aspects of the route and the efforts of individual cyclists enthralled listeners throughout the country and for a short-lived period overrode deep-seated political feuds and animosities"(Londoño Vega, Londoño Vélez, 1989, Iv: 370).

After briefly reviewing the political realities of Colombia in the 1950s, this essay traces the history of Colombian cycling in the first half of the twentieth century and the simultaneous development of radio that was creating an audience for sport spectacles. Presented in this context, the analysis of the January 1951 Vuelta that follows offers a new perspective on the policies adopted by the Conservative President Laureano Gómez during the Violencia. Based on contemporary sources, it also seeks to explain why professional cycling emerged second only to soccer, known locally as fútbol, as the nation's most popular sport and why Colombians have embraced their pedalistas (cyclists) with a passion unique in Latin America. ${ }^{2}$

\section{The 1940s: Political Turbulence and the Beginning of the La Violencia}

In the first half of the twentieth century, the traditionally intense animosity between the Conservative and Liberal parties rose to a fever pitch after the disputed election of 1946 brought the Conservative candidate Mariano Ospina to the presidency. Two years into his administration the murder on April 9, 1948 of populist Liberal leader Jorge Eliécer Gaitán touched off a riot of unprecedented proportions that later became known as the Bogotazo. On the initial (though erroneous) assumption that Ospina's government had ordered Gaitán's murder; the event further inflamed hatreds between Conservatives and Liberals creating a de facto civil war that Ospina's government was powerless to control. Tensions heightened on November 9, 1949 when Ospina Pérez closed Congress, decreed a state of siege, limited civil liberties and assumed discretionary powers. These draconian moves were followed in 1950 by the election of ultra Conservative Laureano Gómez in a contest boycotted by the Liberals (Rausch, 2013, 30).

On January 1, 1950 president-elect Gómez delivered a new year's greeting to the nation that promised a bright future if everyone would work together in a spirit of patriotic harmony. Unfortunately, especially in Andean rural areas La Violencia only intensified, and the death toll during Gómez' first year in office reached 50,000 (Henderson 2001, 322). Expanding into new regions (eventually all of Colombia except the Caribbean area was affected), the conflict increasingly assumed the nature of a class struggle as peasants defied the efforts of landowners and their hired thugs to eject them from their parcels, and Communist Party activists began organizing uprooted peasants into self-defense strongholds. The period between 1949 and 1953 saw a rise of resistance in guerrilla zones inhabited by peasants and fugitives fleeing from regions marked by anarchy or terror, many of which were located in the llanos, the plains covering vast expanses in the eastern part of the country. As Robert Dix points out, "The guerrilla bands were spontaneous in origin, restricted in their range of operation, and limited in their goals - which were 
often those of self-defense or revenge against local political enemies or local officials" (Dix 1966, 322).

On October 28, 1951, Gómez suffered severe heart attack that forced him to relinquish power to Vice President Roberto Urdaneta Arbelaéz. Nevertheless, he continued to direct the government from his sickbed. Gómez attempted "to restore order through the principle of centralized, vertical and hierarchical authority" by turning back the clock on reforms promoted by previous Liberal administrations, but his policies were only partially successful (Osterling, 1989, 91). Although the national economy improved, wages lagged behind prices; the government forcibly broke up strikes, and for laborers it was the worst of times. Given this chaotic situation, the simultaneously emergence of professional sports such as cycling and soccer (largely overlooked by scholars of the period) offered a welcome distraction from the grim realities of daily life. ${ }^{3}$

\section{The Introduction of Radio in the Early Twentieth Century}

Notwithstanding occasional political turbulence, many aspects of modern life had made their way into Colombia during the first half of the twentieth century. One of the most far-reaching developments was the adoption of relatively simple equipment that could transmit by radio all types of messages. By the 1930s Colombia had access to technology that permitted long distance radio diffusion. This new medium quickly emerged as a means of communication that could circumvent geographical obstacles that had long bedeviled national integration (Castrillón Gallego 1915, 3).

Commercial radio stations began operations in the United States in the 1920s. In those years, Colombians, if they owned short-wave receivers, could hear programs broadcast from the US as well as Mexico, Buenos Aires, and Havana. On April 2, 1923 President Pedro Nel Ospina officially inaugurated the first national radio station in Engativá, Cundinamarca. His successor, Miguel Abadía Méndez authorized public radio broadcasting over station HJN or Radio Nacional in Bogotá on August 7, 1929. The following December the first privately owned station, KHD "La Voz de Barranquilla" went on air and, in January 1930 Gustavo Uribe Thornschmidt and Roberto Jaramillo established the first commercial radio station, HKF. On February 28, 1931 President Enrique Olaya Herrera issued Decree no. 423 designed to facilitate the process of radio licensing and operation, and, in 1935 Cine Colombia obtained the right to import and distribute RCA transmitters throughout the country. As a result, the number of stations dramatically increased from 17 in 1934 to 70 in 1941. By that year, most major cities in Colombia had at least one broadcasting station, and Bogotá and Medellín each had six (Pareja 1984, 20-32).

At its inception, Colombian leaders considered two models of radio broadcasting. The first was the European model of state-controlled radio in which governments monopolized the content of programs and financed operations by licensing each radio station and collecting from it a monthly or annual fee. The second model, adopted by the United States, gave private interests a free rein to broadcast whatever they wished, while relying on advertisements to pay for the programs. Before 1934 Colombian leaders experimented by mandating a state-controlled system, but after that year, when there were already 5,000 receivers in the country, commercial radio expanded the listening audience and gradually dominated the airways (Pareja 1984, 16; Uribe Celis 1992, 67). ${ }^{4}$

From the beginning of 1930s, Colombian stations explored the feasibility of covering major sports events. The country received sports transmissions first via telephone from the US in 1922, but, with the introduction of broadcasting using transmitters and FM frequency modulation, it was possible for Colombian sportscasters located at an actual sport arena to narrate events back to a central broadcasting station. When automobile races, soccer contests, and international competitions such as the Bolivarian Games of 1938 could be described as they were happening via radio, the programs, sponsored by advertising from a multitude of companies, quickly attracted a massive following.

By the 1950s, an estimated half a million Colombians owned receivers. President Gómez astutely realized that radio provided the most immediate way to reach out to all regions of the country and that sports were an excellent way to distract the public from accounts of horrific violence sweeping the country. Athletic competitions filled 25 percent of commercial programming during his regime while radio emerged as the primary vehicle the promotion of soccer, boxing, and athletic contests, and for building popular cults around players and teams (Pareja 1984, 82).

Sports commentators played a key role in this development. The most prominent was Carlos Arturo Rueda Calderón (1918-1995), who is generally regarded as the "inventor" of Colombian sports narration (El Tiempo, June 23, 1995). Rueda Calderón was born in San José, Costa Rica on October 28, 1918, the son of Alfredo Rueda, a politician from Santander who had relocated to Costa Rica during the turmoil caused the War of a Thousand Days (1899-1903). The Rueda Calderón family later moved on to Caracas where Carlos at age 11 narrated his first game - a baseball contest played by his school - for Radio Caracas. In 1934 the family moved again, this time to Bogotá, and Carlos Arturo, who was training to be a boxer, applied to the Nueva Granada Broadcasting system for the opportunity to transmit directly from the Teatro Olimpia a boxing bout between Colombian Francisco Mamatoco Pérez and Trindadian Bill Scott. Rueda was only sixteen years old at the time, but his commentary was a success, and he earned seven pesos for his effort. His next exploit was to go to the office of another station, Broadcasting (one of the broadcasting stations [emisoras] of the time) 
to hire him to narrate soccer games played on the fields of the Colegio San Bartolomé in Bogotá. To convince the directors of his qualifications, he narrated an imaginary game naming all the players. After this feat, his ability was well established (El Tiempo, June 23, 1955). In 1936, the organizers of the Bolivarian Games taking place in Bogotá hired Peruvian Juan Cedón to narrate the events keeping Carlos Arturo as a kind of substitute in case Cedón needed assistance. During the intermission of a basketball game between Colombia and Peru, an inebriated Cedón ceded the microphone to Rueda: "By the end of the game, the Peruvian, deeply impressed by Rueda Calderón's commentary, resigned while still on the air, saying: 'I am not needed here, because you have the best sportscaster in all America"' (Semana, July 10, 1995).

In 1938 Rueda Calderón became a naturalized Colombian citizen and married Liliana Tirado of Manizales. Hired the previous year by Radio Manizales, he had already created a popular sports program Momento Deportivo (A Moment in Sports), which he opened with the soon to become famous line: "I, Carlos Arturo say..." Momento Deportivo was his true launch into Colombian radio. Soon he was receiving dozens of offers to narrate soccer, boxing, basketball, and athletic contests. Working for various stations, he toured the country until the Bogotá station Nueva Granada offered him regular employment with an attractive salary of 240 pesos monthly plus the rent of a furnished apartment (El Tiempo, June 23, 1995).

Carlos Arturo was a revolutionary in his profession. Before him, sports in the country were distant and far from the people, but this gifted announcer created images of the events, added humor to his commentary and gave distinctive nicknames to the players. His emotional call of gooool! during a soccer game in 1938 became one of his most enduring legacies, and he never left his listeners without knowing what had happened at the end of a cycling stage or a football game. In the opinion of El Tiempo, "His work stood out for three aspects: the creativity of his phrases, the velocity of his accounts, and the nicknames he gave to everyone (El Tiempo, June 23, 1995). There is little doubt that the impact of his narration of the Vuelta a Colombia in January 1951, coming in the early part of his career, was a critical component to the rise of the Colombian passion for cycling that endures to this day.

\section{The Arrival of Bicycles to Colombia}

The adoption of bicycles in Colombia closely mirrored their introduction into the cultures of other Western World countries. In the early 1890s, Ernesto Duperly Desnoües began importing the two-wheeled devices still known as velocipedes (velocípedos in Spanish), first to Cartagena and then to Bogotá. ${ }^{5}$ By 1894, Colombian newspapers were reporting that the new machines, already enthusiastically embraced by Europeans, were popular in Bogotá among both men and women. On July 22 of that year, the first race of velocipedes with prizes for the winner took place (Londoño Vega, Londoño Vélez 1989, IV: 361). By 1896 sales of Columbia and Hartford brand bicycles were flourishing in the more populous cities. Two years later one hundred aficionados in Bucaramanga started the first organized bicycle club, the Sociedad Ciclista. Meanwhile, in Bogotá, ciclistas, urged on by Guillermo Pignalosa, who later became the director of the Asociación Colombiana de Ciclismo (Aciclismo), began competing in short races between Calle 26 with Carrera 7 , and from Calle 63 to the north, returning via Carrera 13. Two velódromos (velodromes) — one in the Plaza de los Mártires and the other in the Quinta de la Magdalena-were built specifically for the use of cyclists (Forero 1989, VI: 371). In rural areas peasants and farmers continued to rely on mules and burros for transportation, but during the first half of the twentieth century, bicycles proliferated in the towns. Many youths found employment by using bicycles to make deliveries of market purchases or as messengers for local establishments. Soon bicycle racing was a popular event in department capitals, municipalities, veredas (districts), and along the roads.

In 1896, at the first Olympic games held in Athens, the International Olympic Committee included track cycling, but road racing in Europe (with the exception of England, where track racing was preferred) quickly became the most prominent and popular manifestation of competitive cyclists. These races had the advantage of being accessible to all. Since no tickets were required, the public could gather along the roadsides of the route and cheer the riders on as they streaked by. Reports of these European races in the local media clearly increased Colombian enthusiasm (Credencial Historia 205, No. 181).

The Tour de France was the first national road race. Sponsored by the Paris newspaper L'Auto, it took place July 1-19 in 1903. The cyclists rode some 2,428 kilometers in six stages through French terrain that passed through the Pyrenees and the Alps. At the end of this grueling ordeal, Maurice Garin emerged as the winner. In 1909, the Italian newspaper $L a$ Gazzetta dello Sport organized a similar race, the Giro d'Italia. Luis Ganna won this competition, which covered 2,448 kilometers of Italian territory in 8 stages. Not to be outdone, in 1935 Spain inaugurated the Vuelta a España, but the Tour de France, held annually (with the exception of the years during the two world wars), retained its status as the Holy Grail for aspiring bicycle racers. As historian David Herlihy writes in Bicycle: The History: "Tales of heroic cyclists in the mountaintops fighting off their rivals and the elements quickly became part of popular lore" (Herlihy 2004, 385). Such reports further motivated Colombian cyclists who were participating in shorter races between Bogotá and Tunja; Tunja and Bucaramanga; and Medellín and Sonsón. In 1938, cyclists took part in the first Juegos Deportivos Bolivarianos 
held in Bogotá to mark the 400th anniversary of the founding of the city, and the government issued Decreto 2216 creating the Asociación Colombiana de Ciclismo (Aciclismo) to organize bicycle sports in the country. ${ }^{?}$

\section{The First Vuelta a Colombia}

Between February 28 and March 12, 1950, undeterred by the violence sweeping their country, Colombian athletes participated in the Juegos Centroamericanos y del Caribe held in Guatemala City. In its 4,000-kilometer bicycle race, Zipaquireño Efraín Forero Triviño set a new championship record in defeating teams from Mexico and Cuba. On mounting the victors' podium and hearing the national anthem, the 19-year-old Forero was deeply moved by the international prestige cycling had brought to his country (Forero Nougué 1989, VI: 372). His impressive success would win him the sobriquet "The Indomitable Zipa," and he was to become the first of Colombia's cycling heroes (Rendell, 2002, 7).8

Ten years earlier cyclists had begun to think seriously about holding a Vuelta a Colombia à la the Tour de France, but their dreams were stymied by the abysmal conditions of the country's roads (many of which were barely passable on foot), and also by the unprecedented political violence that had intensified after the assassination of Jorge Eliécer Gaitán in 1948. The idea was born in Bogotá around the tintos and tragos (coffee and drinks) of the tables of the Café Pasaje between November and December of 1950. Two journalists for El Tiempo, Pablo Camacho Montoya and Jorge Enrique "Mirón" Buitrago together with Efraín Forero, Mariano Martínez, Guillermo Pignalosa and Donald Raskin decided to approach Enrique Santos Castillo, editor-in-chief of $\mathrm{El}$ Tiempo, to suggest that the paper sponsor a race similar to the Tour de France. Santos had grave doubts about the viability of such an extensive race. While races held between Bogotá and Tunja had been successful, one that would take cyclists through departments with roads less well maintained seemed problematic. To prove that such a contest was possible, Forero, Raskin, and Martínez decided to make a trial run from Bogotá via Honda to Manizales, capital of Caldas, a distance of approximately 300 kilometers. With Forero on his bicycle and Raskin and Martínez following by car, no difficulties were encountered between Bogotá and Honda. In Honda the Ministry of Public Works provided a pickup truck, but the driver did not think it was possible to drive to Manizales, and, after reaching Padua, he refused to continue. Nevertheless, Forero pedaled ahead to Manizales, and the others arrived by car some two hours later. Once the group returned to Bogotá to report their success, Santos complied with his promise to sponsor the Vuelta (Galvis 1997, 85).

The organizers laid out the proposed race to cover 1,254 kilometers during January 5-16. They divided it into ten stages interspersed by two rest days (listed below) that traversed through Cundinamarca, Cauca, Antioquia, and Caldas:

The First Vuelta a Colombia (El Tiempo, January 4, 1951)

\begin{tabular}{|c|c|c|c|}
\hline Stage- Sponsor & Date & Route & Distance (Kms) \\
\hline 1. Avianca & January 5 & Bogotá- Honda & 163 \\
\hline 2 Asociación Nacional Atlético & January 6 & Honda-Fresno & 41 \\
\hline \multirow{2}{*}{3 Bavaria } & January 7 & Fresno-Manizales & 100 \\
\hline & January 8 & Rest in Manizales & \\
\hline 4 El Tiempo & January 9 & Manizales-Cartago & 76 \\
\hline \multirow{2}{*}{5 Flota Grancolombiana } & January 10 & Cartago-Cali & 210 \\
\hline & January 11 & Rest in Cali & \\
\hline
\end{tabular}


The First Vuelta a Colombia (El Tiempo, January 4, 1951)

\begin{tabular}{|c|c|c|c|}
\hline Stage- Sponsor & Date & Route & Distance (Kms) \\
\hline 6 El Tiempo & January 12 & Cali-Sevilla & 169 \\
\hline 7 Avisos Zeón & January 13 & Sevilla-Armenia & 63 \\
\hline 8 Bavaria & January 14 & Armenia-Ibagué & 100 \\
\hline \multirow{2}{*}{9 Avianca } & January 15 & Ibagué-Giradot & 88 \\
\hline & January 16 & Rest in Giradot & \\
\hline 10 Millonarios & January 17 & Girardot-Bogotá & 140 \\
\hline
\end{tabular}

As sociologist David Quitián observes, all these stages were held in Andean departments and followed routes carefully devised to circumvent areas where incidents of violence were still intense - a pattern that would continue for the next six annual Vueltas. ${ }^{9}$ Fashioned in this way, he argues, and promoted by radio, the Vuelta along with the organization of professional soccer (begun with the first national championship held in Bogotá in 1948), would come to symbolize the difference between a "civilized country" with its regions pacified and the nation in arms that was outside central control (Quitián 2015). It is important to add that, while laid out to avoid violence, the majority of roads composing the route were riddled with holes, rocks and dust, and, on occasion, covered by streams of water that forced the cyclists to ford on foot carrying their machines. Perhaps only Forero Triviño was truly prepared for such a challenge, since he already had some knowledge of the terrain.

In the weeks leading up to the race, El Tiempo extensively promoted the event describing it as a "Tour Criollo" following the example of the Tour de France. Just as in France, where the competitors were known as routiers, El Tiempo referred to the Colombian racers as ruteros (routers) and it emphasized that the terrain the Colombians faced would be more difficult than that comprising the French race, because the Andes were much higher than any mountains cyclists in Europe might encounter (El Tiempo, January 5, 1951). Santos convinced eight well-established companies - Avianca, Bavaria, El Tiempo, Lansa, Ultra, Flota Grancolombiana, Avisos Zeón, and the Club Deportivo Los Millonarios - to sponsor one or two of the stages. Before registration was closed on December 20, thirty-five cyclists from seven departments had signed up, but only thirty-one actually appeared on January 6: fifteen from Valle; seven from Cundinamarca; three from Nariño; two from Antioquia; and one each from Tolima, Santander and Cauca. Forero from Zipaquirá, Cundinamarca was clearly the favorite, but among the other likely challengers were the antioqueños Roberto Cano and Pedro Nel Gil; Luis Galo Chiriboga and Óscar Oyola from Valle, and Carlos Orejuela of Cundinamarca.

At 8:00am in Bogotá on January 5, 1951 some 3,000 spectators gathered near the starting line on Avenida Jimenéz with Carrera Séptima in front of the offices of El Tiempo. Efraín Forero was the last participant to arrive, causing some concern, but on sighting him "a human avalanche ran to the Parque de Santander, applauding the great zipaquireño," an action reflecting the enormous public admiration he already inspired (El Tiempo, January 6, 1951). The cyclists had no special uniform. Some were wearing fútbol shorts; others had leather caps, and most sported shirts carrying such messages as "Radio Loco los saluda" or "Planta de Soda de Zipaquirá," (Zipaquirá Bottling Co.). Among the bicycles they would ride were five Cazernaves and three Daytons, but the rest were the heavy machines that their owners used to carry bread or correspondence in their employment for some company ( $E l$ Tiempo, January 19, 1951). At 8:08am Pignalosa told the riders to line up, and at 8:10am El Tiempo's "Mirón" lowered the black and yellow flag to start the race.

Once the racers were off, Efrain's brother, Rayado Forero, followed them driving an automobile. With him were Pigalosa, Martínez, Zuleta, and Raskin. Other vehicles included a car loaned by a tailor, Ismael Ramos; a truck hauling the cyclists' equipment; cars sent by Bavaria and the Planta de Soda de Zipaquirá; a Red Cross ambulance, and the RCN transmóvil which carried radio technicians and Carlos Arturo Rueda, who as commentator for the Nueva Granada radio station, initiated the "first, vibrant, and legendary transmission of Colombian cycling" (Silva Guzmán 2017, 17; Caicedo Garzón, 1991). ${ }^{10}$

During the first stage of the race, the cyclists could not avoid accidents despite efforts of the police to clear the route. 
There were falls and broken bicycles, and worst of all, Jorge Ramírez (Valle) collided with an illegally parked auto in Facatativá, fracturing his collarbone. Forero, despite experiencing six tire punctures managed to be the first to reach Honda with an advantage of 23 minutes over the next competitor. On January 6 , as seven thousand supporters cheered him on, Forero was also first to cross the finish line of the second stage in Fresno (El Tiempo, January 7, 1951).

On the morning of January 7, the racers tackled the third stage sponsored by Bavaria. This section was considered one of the most difficult since it involved the racers climbing the Alto de las Letras to an altitude of 3,400 meters and then descending to some 50 meters above sea level. It was during that descent that Forero suffered a violent fall, landing in a ditch. His right knee was injured, but fortunately his bicycle was undamaged. Forero's mother, who was a passenger in one of the accompanying cars, helped him to remount, and he was able to make up the distance he had lost to win the stage with a time of 5 hours and 41 minutes - four minutes ahead of the second finisher, Roberto Cano (El Tiempo, January 8, 1951).

Alberto Galvis suggests that the first doping incident in the history of Colombian cycling took place during the rest day in Manizales. Carlos Casas Morales, the Vuelta's official doctor, provided some tablets to the racers to strengthen and protect them from the cold because he believed their extreme efforts were going beyond normal human limits. ${ }^{11}$ For extra endurance the cyclists drank herb tea and ate panela (hard, brown sugar). They spent the day making repairs to their bicycles and relishing the spontaneous support they were receiving from fellow citizens. For example, Avianca delivered to José Álvaro a new bicycle along with some money that had been collected in his hometown of Facatativá. Carvajal y Compañía, the multinational based in Cali, sent a jeep with spare parts to their cyclist, Galo Chiriboga. Antonio Garcés Uribe brought from Envigado two bicycles, spare parts, and money for the antioqueños Cano Ramírez and Pedro Nel Gil, but unfortunately the bikes were too heavy to be used unless there was an emergency. Letters, including several offers of marriage, arrived from all parts of the country to further encourage the cyclists. ${ }^{12}$

By the time the bikers set out on the fourth stage on January 9, sponsored by El Tiempo, many additional cars had joined the caravan that would follow the cyclists through Antioquia and Valle. Accompanying Carlos Arturo Rueda in his transmóvil were vehicles transporting "coaches, quacks and pseudo-mechanics, motorcyclists, and mothers of the racers who frequently asked if they were in pain, prepared their favorite food, put them to bed, and lighted candles to pray for them" (Galvis 1997, 86).

Forero had hoped to win all ten stages of the Vuelta, but on the fourth stage he arrived in Cartago 33 seconds behind the antioqueño Roberto Cano, and during the fifth and longest stage sponsored by Flota Grancolombiana, he collided with a car causing unanticipated delay. While not seriously injured, he finished second in Cali behind Oscar Oyola from Valle, where they were greeted by 50,000 fans (El Tiempo, January 11, 1951).

Forero did manage to win four of the last five stages in spite of mechanical difficulties. The exception was the Avianca ninth stage when his bicycle chain broke three times causing delays that prevented him from beating Oyolo in Girardot. On the eighth stage sponsored by Bavaria, he was the first to cross the finish line despite riding on the rims of his bicycle's wheels due to a flat tire that occurred on the descent into Ibague. At the end of the tenth stage, he arrived in Bogotá two hours, 19 minutes and 48 seconds ahead of Roberto Cano, who was in second place (Silva Guzmán 2017, 18; Rendell 2002, 22).

On entering Muzú in the southern zone of Bogotá, Forero found a crowd of some 30,000 persons waiting to receive him. By wining the first Vuelta a Colombia, he had become a great national sport hero who radio commentator, Carlos Arturo Rueda nicknamed "the Indomable Zipa" (Silva Guzmán 2017, 18). Closely following the racers, Rueda had broadcast the details of each of the stages as they were happening. ${ }^{13}$ Since by 1950 there were half million battery operated radio receivers in a country of $11 \frac{1}{2}$ million inhabitants, his "play by play" account, replaced for a time reports of La Violencia's horrors. Reaching out, not just to the common people in the towns, but also to campesinos in the rural areas throughout Colombia, Rueda's broadcast of the Vuelta helped to create a sense of a "single country - discernible and indubitable" (Uribe Celis 1992, 96). Historian Castrillón Gallega adds the following: "Much of the collective memory that was constructed about this event was due to the voice of Carlos Arturo Rueda, the names with which he baptized the racers... and his magnificent narratives" (Castrillón Gallego 1915, 6). ${ }^{14}$

\section{The Vuelta's Aftermath}

Thirty cyclists completed the Vuelta. Listed below are the first ten finishers along with their team identifications and times: (Vuelta a Colombia 1951). 


\begin{tabular}{|c|c|c|c|}
\hline Position & Cyclist & Team & Time \\
\hline $\mathbf{1}$ & Efraín Forero & Cundinamarca & $45 \mathrm{~h} 23 \mathrm{~min} 8 \mathrm{~s}$ \\
\hline $\mathbf{2}$ & Roberto Cano & Antioquia & $+2 \mathrm{~h} 19 \mathrm{~min} 48 \mathrm{~s}$ \\
\hline $\mathbf{3}$ & Pedro Nel Gil & Antioquia & $+2 \mathrm{~h} 37$ min $0 \mathrm{~s}$ \\
\hline $\mathbf{4}$ & Luis Galo Chiriboga & Valle & $+4 \mathrm{~h} 48$ min $37 \mathrm{~s}$ \\
\hline $\mathbf{5}$ & Carlos Orejuela & Cundinamarca & $+4 \mathrm{~h} 48 \min 37 \mathrm{~s}$ \\
\hline $\mathbf{6}$ & Leoncio Celis & Cundinamarca & $+4 \mathrm{~h} 55 \min 39 \mathrm{~s}$ \\
\hline $\mathbf{7}$ & Óscar Oyola & Valle & $+5 \mathrm{~h} 10 \mathrm{~min} 13 \mathrm{~s}$ \\
\hline $\mathbf{8}$ & Juan José Medina & Valle & $+5 \mathrm{~h} 52 \mathrm{~min} 16 \mathrm{~s}$ \\
\hline $\mathbf{9}$ & Marino Gutiérrez & Valle & $+7 \mathrm{~h} 44 \mathrm{~min} 46 \mathrm{~s}$ \\
\hline $\mathbf{1 0}$ & Carlos Buitrago & Cundinamarca & $+8 \mathrm{~h} 0 \mathrm{~min} 8 \mathrm{~s}$ \\
\hline
\end{tabular}

It should be emphasized that all the cyclists were from the lower class. By attempting what was then regarded as almost an inhuman feat, their main object was to escape povertyto overcome their own physical limits and to win prizes to support their families. A victory in even one stage of the Vuelta offered the possibility of patronage and employment.

Such hopes bore immediate fruit. Massive festivals awaited the participants in their hometowns irrespective of their positions at the end of the race. Zipaquirá declared January 20 a day of celebration, and the townspeople took to the streets to greet Forero. José Alfaro, thirteenth overall, was welcomed as a hero in Facatativá. In Bucaramanga, Alonso Navas, sixteenth overall, and nearly ten hours behind Forero, was accompanied from the airport by a procession led by twenty motorcyclists in single file, 300 cyclists, and numerous cars fêting Navas with their horns. Such scenes were repeated wherever riders were returning home (Rendell 2002, 22; El Tiempo, January 20, 1951).

The racers also received prizes from various commercial houses and private entities. For example, Panavián donated to Forero as the absolute winner a free trip to anywhere in Colombia; Almacenes Ley awarded him a silver trophy, and he collected other trophies from the Asociación Nacional de Industriales (ANDI) and the office of the Jefatura Nacional de Educación Física (National Direction of Physical Education) of the Ministry of de Education. Other cyclists won silver trophies, cameras, cocktail shakers, travel tickets, records, hats, and bottles of champagne.

The extent of this largesse alarmed President Eduardo Santos Castillo and Secretary Donald Raskin of Aciclismo.
On January 18 they sent a letter to all the national newspapers explaining that the Association could not permit the racers to accept these prizes - an action that might jeopardize their amateur status. Their letter stated that to avoid this result, Aciclismo itself would collect all money that had been offered and use it to buy spare parts and accessories to repair the racers' bicycles. It would invest any remaining funds in purchasing trophies for the winners of different stages (Galvis 1997, 88). Despite this directive, the association did not prohibit Forero from accepting the greatest prize - an invitation received on January 18 from the French Embassy in Bogotá to participate in one of the trials for the Tour de France (Galvis 1997, 89). ${ }^{15}$

There were other winners of the first Vuelta a Colombia. El Tiempo, which spent just 7,000 pesos (6,500 of which paid for the hotel stays of the racers) to sponsor the race, gained enormous publicity from its daily coverage of its progress throughout January 1951. For the embattled Gómez-Urdaneta Arbeláez's government, the Vuelta created a distraction from the incidents of violence occurring throughout the Andean and plains regions. The mesmerizing commentary of Carlos Arturo Rueda, by reaching every corner of the country, transformed the previously anonymous cyclists into heroes in addition to demonstrating the role radio would play in creating a sense of Colombian nationalism within distinct regions.

Perhaps the sport of cycling was the most obvious winner. As David Quitían points out, the Vuelta had been an invention of Bogotá elites. Supported by the communication media, the race transformed an activity previously reserved to the aristocracy and lowly urban employees who used bicycles in their work, into a sport accessible to any young man who 
had a bicycle and the determination to challenge Colombia's mountains to win personal glory and improved social status (Quitían 2015, 5).

Aciclismo immediately began planning for a second Vuelta a Colombia to be held in 1952. Frenchman José Beyaert won this contest that followed a triangular route between the three principal Andean cities of the country-Bogotá-Cali-Medellín-, but the next four annual Vueltas were captured by antioqueño Ramón Hoyos Vallejo, who replaced Forero as the foremost Colombian cyclist of the 1950s. While broadcasting the Vuelta in 1953, Carlos Arturo Rueda baptized Hoyos "El escarabajo de la montaña" (the mountain's beetle) and, by extension, Colombian cyclists ever after adopted the name "Los escarabajos" as a badge of honor (Credencial Historia 2005, No. 181).

\section{Conclusion}

It is difficult to argue that the Vuelta fundamentally transformed the nature of the political violence that engulfed Colombia during the Gómez-Arboleda regime. Nevertheless, as David Quitían argues, the popularity of the radio broadcasts of the race opened a crack in partisan hatreds by creating new heroes for the Colombian people and by giving them a more positive view of their country. The cyclists so extolled by Carlos Arturo Rueda were not the traditional warriors, i.e., politicians, soldiers, bandits, and guerrillas, but campesinos, messenger boys, and gardeners transformed into brave athletes. The race created an "imagined community," a nation characterized by the tenacity of the escarabajos and their "steel machines" (Quintían 2015, 5).
On June 13, 1953, General Gustavo Rojas Pinilla led a military coup that overthrew the Gómez regime. One of his first acts was to declare an immediate amnesty for all those involved in the violence except military deserters. Between July and September 1953 over ten thousand guerrillas accepted the government's terms and, by the year's end, resettlement workers helped nearly five thousand people displaced by La Violencia to return to their homes. Rojas continued to support the annual Vueltas, and they survived the downfall of his regime on May 10, 1957, as did the resurgence of $L a$ Violencia.

Over the last eighty years Colombian cyclists have gone on to win fame in Europe as well as their own country. In his monograph, Ciudadanos, calles y ciudades, Ricardo Montezuma confesses that little is known about why the bicycle became so deeply rooted in many regions of Colombia starting in the 1950s, but he adds that it is quite likely that a key element "was the strong fan base for bicycle racing and the fervor awakened in 1951 by the country's longest race, the Vuelta a Colombia" (Montezuma 2011,39). Silva Guzmán strongly supports Montezuma's conclusion, for he states unequivocally, that it was the excitement created by the courage and daring of the first competitors in the first Vuelta what sparked "the most beautiful and romantic launch of a national sport" (Silva Guzmán 2017, 19). Clearly, the running of the annual Vuelta did not end La Violencia for, reignited in the late 1950s, it would continue on for another decade. Nevertheless, the very existence of the race provided Colombians with a defiant alternative to civil war and class hatreds as well as an opportunity to embrace a positive view of their nation.

\section{Notes}

1. Anyone who watched the frenzied spectators at the 2018 FIFA World Cup tournament in Russia will readily understand the role that nationalism plays in international sport contests. An excellent theoretical explanation of this phenomenon can be found in the "Introduction" of Sports and Nationalism by Fernández L'Hoeste, McKee Irwin, and Poblete (2015, 1-18)

2. In his "Boxing in the Making of a Colombian Costeño Identity," Sheinin underscores that boxing preceded both ciclismo and fútbol as a professional sport in Colombia. Largely practiced by Afro-Colombians living along the Caribbean coast, its popularity emerged in the 1920s and continued until the 1970s. See Sheinin 2015, 141.

3. Henderson, who provides the most complete account of the Gómez presidency in Modernization in Colombia, omits any mention of the efforts of his government to support the development of amateur and professional sports. See Henderson 2001.

4. For the most recent history of radio in Colombia during the first half of the 20th century, see Castrillón Gallego 2015.

5. For a comprehensive history of the evolution of the bicycle, see Herlihy 2004.

6. Forero Nougués adds that Pignalosa "was the great animator of the era not only thanks to his aptitude but to his bicycles imported from Italy which were the most modern of the time" (Forero Nougués 1989, 371). 
7. In 1980 Aciclismo was renamed the Federación Colombiana de Ciclismo." See Rendell, 2002, 131.

8. Before the arrival of the Spanish, Zipaquirá had been a Muisca settlement headed by a chieftain known as the Zipa. It was the radio narrator of the Vuelta a Colombia, Carlos Arturo Rueda, who first referred to Forero as "El Zipa Indomable."

9. It was not until the running of seventh Vuelta, that the race included the Caribbean coast. In 1957, the route, shaped in an inverted "T", began for the first time in Barranquilla and continued on to Cali and Bogotá. The earlier omission of the Caribbean region was not due to violence (for the coast had remained largely peaceful), but was more likely caused by its distance from Bogotá and the lack of roads suitable for bicycles. Thus, Fernández L'Hoeste maintains, the Vuelta was not truly "national." While conceding that it did create a certain identity construct "as the reigning paradigm for Colombian nationality in sports," he concludes that enthusiasm for cycling was largely an Andean phenomenon (Fernández L’Hoeste 2015, 93).

10. The transmóvil was a unique Colombian invention probably designed by Carlos Arturo Rueda. As defined by the Ministerio de Tecnologías de la Información y las Comunicaciones, it was a kind of truck having no specific geographic location that was equipped with a communication system. It included a broadcasting station, a radio receiver, and a relay station. Colombian historian Herbert "Tico" Braun recalls seeing the transmóviles as a youth. He writes: "I remember them well, not in 1951, but later, RCN, Todelar, Caracol. And I have the voice of Carlos Arturo Rueda in my head. We used to go to school with small transistor radios and an earphone, to listen to the Vuelta a Colombia all day long, rather than learn academic stuff. I remember those trucks, with a hole at the top and Rueda's head poking out when the Vuelta arrived in Bogotá." (Email to author, July 23, 2018)

11. Galvis is the only author to mention this incident, and he does not identify the substance that Casas Morales provided (Galvis 1997, 86).

12. El Tiempo, January 10, 1951.

13. For example, in Zipaquirá, Forero's family gathered in his father's drugstore and listened to his Emerson 1932 radio receiver to follow the progress of the Vuelta. See Semana, January 13, 1951.

14. Castrillón adds that during the X Vuelta a Colombia in 1960, the Asociación Colombiana de Ciclismo praised Radio RCN for its support of the event and especially for the outstanding work of Carlos Arturo Rueda.

15. Forero's trip to France was delayed until 1953.

\section{Works Cited}

Caicedo Garzón, Armando. 1991. "Clave 1951 Primera Vuelta a Colombia," December 16. El Tiempo.com. Archivo Digital de Noticias de Colombia y el Mundo desde 1990.

Castrillón Gallego, Catalina. 2015. "Algunos aspectos de la radio difusión y del ciclismo colombianos." In Revista de Extensión Cultural de Antioquia. (July): 1-3.

. 2015b. Todo viene y todo sale por las ondas: Formación y consolidación de la radio difusión colombiana, 1929-1954.

Medellín: Editorial Universidad de Antioquia.

Dix, Robert H. 1966. Colombia: The Political Dimensions of Change. New Haven: Yale University Press.

El Tiempo, January 5, 6, 7, 8, 10, 11, 19, 20, 1951; June 23, 1995.

“Escarabajos de dos Ruedas: los velocipedistas.” 2005. In Credencial Historia, no. 181:1-7.

Fernández L'Hoeste, Hector, Robert McKee Irvin, and Juan Poblete, eds. 2015. Sports and Nationalism in Latin/o America.

New York: Palgrave MacMillan.

Forero Nougués, Mike. 1989. "El deporte en Colombia.” In Nueva Historia de Colombia VI: 351-390. Bogotá: Planeta. 
Galvis, Alberto. 1997. Grandes hazañas de Colombia. Bogotá: Ediciones Martínez Roca.

Henderson, James D. 2001. Modernization in Colombia: The Laureano Gómez Years, 1889-1965. Gainesville: University Press of Florida.

Herlihy, David V. 2004. Bicycle: The History. New Haven, London: Yale University Press.

Londoño Vega, Patricia and Santiago Londoño Vélez. 1989. "Vida diaria en las ciudades colombianos." In Nueva Historia de Colombia IV: 313-399. Bogotá: Planeta.

Montezuma, Ricardo. Ciudadanos, Calles y Ciudades. 2011. Bogotá: Universidad del Rosario.

Osterling, Jorge P. 1989. Democracy in Colombia: Clientelist Politics and Guerrilla Warfare. New Brunswick, N.J.: Transaction.

Pareja, Renaldo. 1984. Historia de la radio en Colombia 1919-1980. Bogotá: Servicio Colombiano de Comunicación Social.

Quitián, David. 2015. “La Vuelta a Colombia: una historia de nación.” August 16. https://www.razon pública.com/indes/php/ suscribse.html

Rausch, Jane. 2013. Territorial Rule in Colombia and the Transformation of the Llanos Orientales. Gainesville: University Press of Florida.

Rendell, Mike. 2002. Kings of the Mountains: How Colombia's Cycling Heroes Changed Their Nation's History. London: Aurum Press.

Semana, July 10, 1995.

Sheinin, David M. K. 2015. "Boxing in the Making of a Colombian Costeño Identity." In Sports Culture in Latin American History: 139-160. Pittsburgh: University of Pittsburgh Press.

Silva Guzmán, Mauricio. 2017. La leyenda de los escarabajos. Bogotá: Aguilar.

Uribe Celis, Carlos. 1992. La mentalidad del colombiano: cultura y sociedad en el siglo xx. Bogotá: Editorial Nueva América.

"Vuelta a Colombia 1951.” 1951. http://es.wikipedia.cor/wiki/vuelta 